\title{
A STUDY OF SACRALISATION OF FIFTH LUMBAR VERTEBRA
}

\section{Rajapur. Parashuram *1, Dakshayani. K.R ${ }^{2}$, Manjunatha S.N ${ }^{3}$, Vadiraja N 4.}

${ }^{* 1}$ Associate Professor, Mysore Medical College and Research Institute, Mysore, Karnataka, India.

2 Professor and HOD, Department of Anatomy, Mysore Medical College and Research Institute, Mysore, Karnataka, India.

${ }^{3}$ Associate Professor, Department of Community Medicine, Mysore Medical College and Research Institute, Mysore, Karnataka, India.

${ }^{4}$ Assistant Professor \& Statistician, Department of Community Medicine, Mysore Medical College and Research Institute, Mysore, Karnataka, India.

\section{ABSTRACT}

Introduction: Sacrum consists of five fused sacral vertebrae. These are fused to provide strength and stability to the pelvis and transmit the weight of the body to the pelvic girdle through the sacro-iliac joints. The vertebral column can bear a weight of nearly $355 \mathrm{~kg}$ without crushing and a tearing strain of nearly $152 \mathrm{~kg}$. Its weakest part is in the neck, which normally carries least weight. Lumbosacral transitional vertebrae (LSTV) are congenital anomalies of the lumbosacral region, which includes sacralisation of fifth lumbar vertebra and lumbarisation of first sacral vertebra observed for the first time by Bertolotti in 1917. This condition occurs due to defect in the segmentation of the lumbosacral spine during development and the combined effect of mutation of homeobox (HOX 11) \& paired-box (PAX1 \& PAX9) gene expression causes several types of sacralisation. Low back pain is quite a common ailment affecting about $80 \%$ of the population in their life time. This abnormality can be diagnosed by plain radiography.

Materials and Methods: In the present study 100 adult human sacra were examined in the department of Anatomy, Mysore Medical College and Research Institute, Mysore, Karnataka.

Observations and Results: In the present study of 100 adult human sacra 71 were male and 29 were female sacra. Out of 100 sacral bones 16 sacra showed sacralisation of fifth lumbar vertebrae and remaining 84 was normal vertebra. Out of 16 sacralised bones, 15 bones showed bilateral sacralisation and only 01 bone showed unilateral sacralisation.

Conclusion: Knowledge of sacralisation is not only enlightening for the orthopaedic surgeons, also vital for the Clinical Anatomists, Radiologists, Forensic experts, Morphologists, Architectures and Anthropologists. Hence we are presenting such variation with emphasize on its clinical relevance. Incorrect numbering during the planning of spinal surgery may have serious consequences.

KEY WORDS: Sacralisation, Lumbar vertebra, Sacrum, Genes, Low back pain.

Address for Correspondence: Dr. Rajapur. Parashuram, Associate Professor, Mysore Medical College and Research Institute, Mysore, Karnataka, India. E-Mail: drparashuram100@yahoo.com

\section{Access this Article online}

\section{Quick Response code}

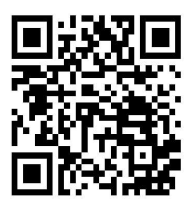

DOI: $10.16965 /$ ijar.2017.156
Web site: International Journal of Anatomy and Research

ISSN 2321-4287

www.ijmhr.org/ijar.htm
Received: 18 Feb 2017

Peer Review: 20 Feb 2017

Revised: 29 Mar 2017
Accepted: 03 Apr 2017

Published (O): 30 Apr 2017

Published (P): 30 Apr 2017

\section{INTRODUCTION}

Sacrum consists of five fused sacral vertebrae. These are fused to provide strength and stabil- ity to the pelvis and transmit the weight of the body to the pelvic girdle through the sacro-iliac joints. The vertebral column can bear a weight 
of nearly $355 \mathrm{~kg}$ without crushing and a tearing strain of nearly $152 \mathrm{~kg}$. Its weakest part is in the neck, which normally carries least weight [1].

The sacrum may contain six vertebrae, by development of an additional sacral element or by incorporation of the fifth lumbar or first coccygeal vertebrae. Inclusion of the fifth lumbar vertebra (sacralization) is usually incomplete and limited to one side. In the most minor degree of the abnormality a fifth lumbar transverse process is large and articulates, sometimes by a synovial joint, with the sacrum at the posterolateral angle of its base. Reduction of sacral constituents is less common but lumbarisation of the first sacral vertebra does occur: it remains partially or completely separate [2].

Lumbosacral transitional vertebrae (LSTV) are congenital anomalies of the lumbosacral region, which includes sacralisation of fifth lumbar vertebra and lumbarisation of first sacral vertebra observed for the first time by Bertolotti in 1917. This condition occurs due to defect in the segmentation of the lumbosacral spine during development [3].

Low back pain is quite a common ailment affecting about $80 \%$ of the population in their life time [4] and it may also cause greater difficulty during labour. This abnormality can be diagnosed by plain radiography.

Knowledge of sacralisation is not only enlightening for the orthopaedic surgeons, also vital for the Clinical Anatomist, Radiologists, Forensic experts, Morphologists, Architectures and Anthropologists.

Thus the present study is carried out to know the proportion and type of sacralisation of the fifth lumbar vertebra.

Aims and objectives: To study the proportion and type of Sacralisation of the fifth lumbar vertebra.

\section{MATERIALS AND METHODS}

Source of data: In the present study 100 adult human sacra were examined in the department of Anatomy, Mysore Medical College and Research Institute, Mysore, Karnataka. Fully ossified adult human sacra of both sexes were included. Damaged, mutilated and deformed sacra were excluded.

Data was collected by naked eye observation for different types of sacralisation of fifth lumbar vertebra depending on fusion (complete and incomplete) and right or left side sacralisation. Sacralised sacra were classified as follows:

1. Complete fusion (fig: 1 ) between the fifth lumbar vertebra and the first sacral vertebra.

2. Incomplete fusion (fig: $2 \& 3$ ) between the fifth lumbar vertebra and the first sacral vertebra.

3. Bilateral sacralisation (fig: 2 ) consists of a bony union between the abnormal transverse process and the sacrum on both sides.

4. Unilateral sacralisation (fig: 3 ) shows a bony union between the abnormal transverse process and the sacrum either on right side or left side.

Study design: Descriptive statistics is done by measuring measures of proportions.

\section{OBSERVATIONS AND RESULTS}

In the present study of 100 adult human sacra 71 were male and 29 were female sacra. Out of 100 sacral bones 16 sacra showed sacralisation of fifth lumbar vertebrae and remaining 84 was normal vertebra (Table 1 ).

Out of 16 sacralised bones, 08 bones showed complete fusion (fig: 1 ) between fifth lumbar vertebra and first sacral vertebra, remaining 08 bones showed incomplete fusion (fig: $2 \& 3$ ) between fifth lumbar vertebra and first sacral vertebra (Table 3).

Out of 16 sacralised bones, 15 bones showed bilateral sacralisation (fig: $1 \& 2$ ) and only 01 bone showed unilateral sacralisation (fig: 3 ) and (Table 2).

Table 1: Gender (sex) wise distribution of sacralisation of fifth lumbar vertebra.

\begin{tabular}{|c|c|c|c|}
\hline & Male & Female & Total \\
\hline No of sacrum & 71 & 29 & 100 \\
\hline Sacralisation of L-5 & 10 & 6 & 16 \\
\hline
\end{tabular}

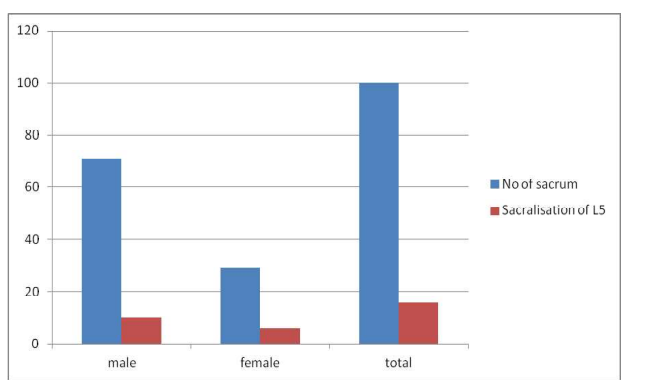


Table 2: Classification of Sacralisation of fifth lumbar vertebra (Total 100 sacra).

\begin{tabular}{|c|c|c|c|c|}
\hline \multirow{2}{*}{ Sex } & \multicolumn{2}{|c|}{ Unilateral sacralisation } & Bilateral & \multirow{2}{*}{ Total } \\
\cline { 2 - 4 } & Right Side & Left Side & sacralisation & \\
\hline Male & 1 & 0 & 0 & 9 \\
\hline Female & $\ddots$ & $\ddots$ & $\ddots$ & 6 \\
\hline Total & 1 & $\ddots$ & 1 & 15 \\
\hline
\end{tabular}

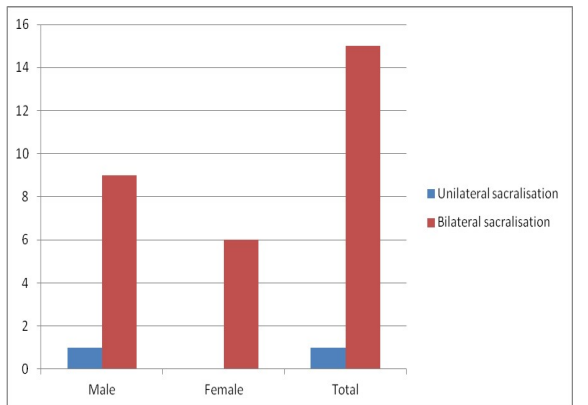

Table 3: Classification of Sacralisation of fifth lumbar vertebra (Total 100 sacra).

\begin{tabular}{|c|c|c|c|}
\hline & Male & Female & Total \\
\hline $\begin{array}{c}\text { Complete } \\
\text { sacralisation }\end{array}$ & $\mathbf{4}$ & $\mathbf{4}$ & $\mathbf{8}$ \\
\hline $\begin{array}{c}\text { Incomplete } \\
\text { sacralisation }\end{array}$ & $\mathbf{6}$ & $\mathbf{2}$ & $\mathbf{8}$ \\
\hline
\end{tabular}

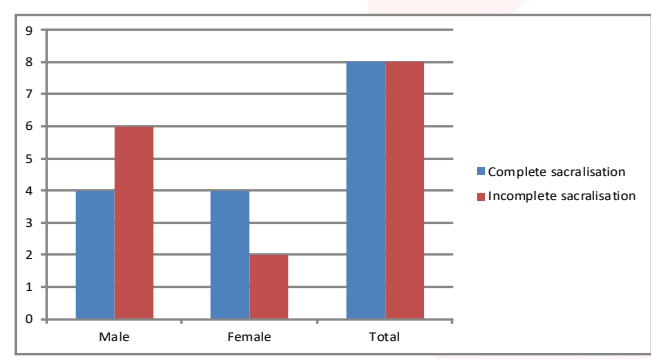

Fig. 1: Bilateral Sacralisation of fifth lumbar vertebra with Complete fusion of fifth lumbar and first sacral vertebrae.
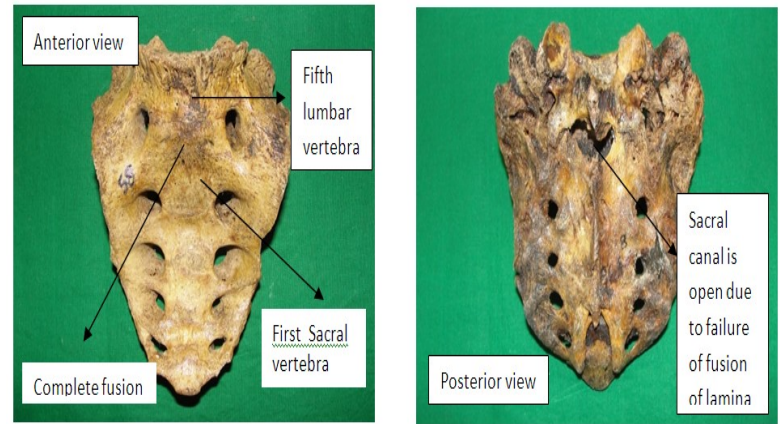

Fig. 2: Bilateral Sacralisation of fifth lumbar vertebra with Incomplete fusion of fifth lumbar and first sacral vertebrae.
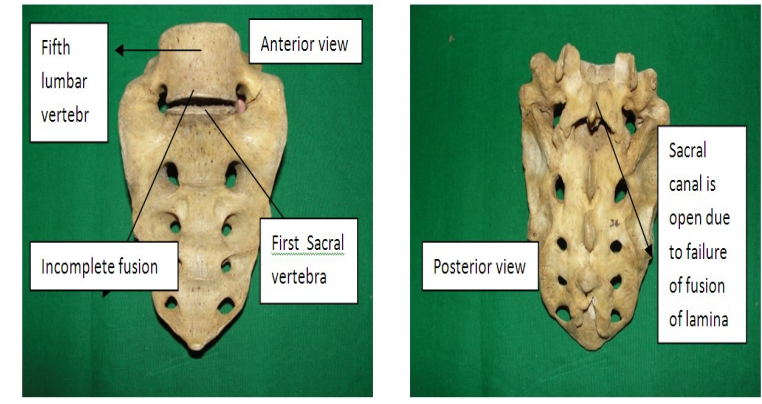

Int J Anat Res 2017, 5(2.1):3718-21. ISSN 2321-4287
Fig. 3: Unilateral Sacralisation of fifth lumbar vertebra on Right side with Incomplete fusion of fifth lumbar and first sacral vertebrae.
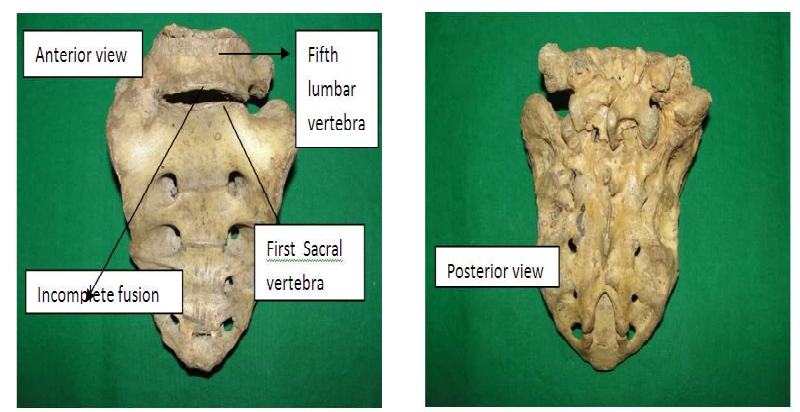

\section{DISCUSSION}

The present study shows that the incidence of sacralisation of the fifth lumbar vertebra is 16 , out of which 10 are male sacra and 06 are female sacra. Based on the literature, the incidence of sacralisation varied by the following races. The incidence in our study was close to the races like Australian aboriginals $18 \%$, Indians $16 \%$ reported by Mitchell and Bustami F respectively and much higher than the races like Americans 3.6\%, Natives of Britain $8 \%$ and Arabs $10 \%$. The incidence of sacralisation was close to the authors reported like Steinberg 14\%, Vandana Sharma 14\%, and the incidence was higher than the authors reported like Kim 1.7\% Hughes 9.2\%, Hald 7.8\%, Hahn 7.5\%, Kubavat $11.1 \%$, Chithrika 5\%. The incidence among Gujarati population is $11.1 \%$ which is more in males than females and Central India region is $14 \%$ [5].

Embryology: Vertebral column develops from the sclerotome, portions of the somites, which are derived from the paraxial mesoderm. During the fourth week, sclerotome cells migrate around the spinal cord and notochord to merge with cells from the opposing somite on the other hand of the neural tube. As development continues, the sclerotome portion of each somite also undergoes a process called resegmentation. Resegmentation occurs when the caudal half of each sclerotome grows into and fuses with the cephalic half of each subjacent sclerotome. Thus, each vertebra is formed from the combination of the caudal half of one somite and the cranial half of its neighbour. Patterning of the shapes of the different vertebrae is regulated by HOX genes [6].

The HOX 11 Group is essential for the genesis 
of sacral and caudal vertebrae (Wellik and Capecchi, 2003) and the overexpression of HOX11 genes is expected to produce signs of sacralisation or caudalisation at other levels of the axial skeleton. This over expression in varying degrees may create variants of the sacrum containing six vertebrae with complete and incomplete fusion of the various components of veretebrae. The combined effect of mutation of homeobox (HOX11) and paired-box (PAX1 and PAX 9) gene expression causes several types of sacralisation [7].

Some authors proposed that sacralisation of the fifth lumbar vertebrae may cause symptoms such as back pain, lumbar disc herniations, spinal pain, radicular pain or lumbar scoliosis. It may cause difficulty during labour because of less mobile pelvis and it may be the reason of low back pain problem.

Table 4: Incidence of sacralisation of fifth lumbar vertebra by various authors.

\begin{tabular}{|c|c|c|}
\hline Race & Incidence & Author \\
\hline Australian aboriginals & $18 \%$ & Mitchell, 1936 \\
\hline Indians & $16 \%$ & Bustami [8] 1989 \\
\hline Arabs & $10 \%$ & Bustami [8] 1989 \\
\hline Natives of Britian & $8.10 \%$ & Brailsford [9] 1928 \\
\hline Americans & $3.60 \%$ & Moore \& Illinois [10] 1925 \\
\hline
\end{tabular}

\section{CONCLUSION}

Knowledge of sacralisation is not only enlightening for the orthopaedic surgeons, also vital for the Clinical Anatomist, Radiologists, Forensic experts, Morphologists, Architectures and Anthropologists. Hence we are presenting such variation with emphasize on its clinical relevance. Incorrect numbering during the planning of spinal surgery may have serious consequences.

\section{Conflicts of Interests: None}

\section{REFERENCES}

[1]. Romanes GJ. Cunningham's text book of Anatomy, $10^{\text {th }}$ editionn, Oxford University press, London;1964:92-93.

[2]. Standring S. Gray's Anatomy: The Anatomical Basis of Clinical Practice, $40^{\text {th }}$ edition, Churchill Livingstone Elsevier, London; 2008:728.

[3]. Bertolotti M. Contributto alla conoscenza dei vici di differenzarione regionale del rachide con speciale riguards all asimilazzione sacrale della v. Lombare. Radiologique Medica 1917;4:113-44.

[4]. Dullerud R. Diagnostic imaging in lumbago and sciatica. Ugeskr Laeger 1999;161:5299-303.

[5]. Dharati K. et al. A study of sacralisation of fifth lumbar vertebra in Gujarat. National journal of medical research 2012;2:211-213.

[6]. Sadler TW. Langman's medical embryology. $11^{\text {th }}$ edition, Wolters Kluwer/ Lippincott Williams and Wilkins, Philadelphia; 2010:142.

[7]. Rajani Singh. Analytical view of the simultaneous occurrence of sacralisation and congenital anomalies. Eur J Anat 2012;16(2):127-130.

[8]. Bustami F. The anatomical features and functional significance of lumbar transitional vertebra. Jordan Med J 1989;23:49-59.

[9]. Brailsford JF. Deformities of the lumbosacral region of the spine. Brit J Surg 1928;16:562-627.

[10]. Moore BH, Illinois C. Sacralization of the fifth lumbar vertebra. J Bone Joint Surg 1925;7:271-278.

How to cite this article:

Rajapur. Parashuram, Dakshayani. K.R, Manjunatha S.N, Vadiraja

N. A STUDY OF SACRALISATION OF FIFTH LUMBAR VERTEBRA. Int J Anat Res 2017;5(2.1):3718-3721. DOI: 10.16965/ijar.2017.156 